\title{
Carbon dioxide in the prevention of air embolism during open-heart surgery
}

\author{
W. SHANG NG AND MICHAEL ROSEN \\ From the Department of Anaesthetics, the Royal Infirmary, Cardiff
}

The factors which are important in the design and use of apparatus for the effective displacement of air by carbon dioxide from chest cavities are examined. High levels of carbon dioxide can be achieved by flowing carbon dioxide at a total flow rate of $51 . / \mathrm{min}$. into the chest cavity through two nozzles of 0.5 to $1.0 \mathrm{~cm}$. diameter. The effect of factors which might diminish the carbon dioxide levels is examined.

During any open-heart operation there is a danger of embolism from air trapped in the heart. One of the ways of reducing this is to displace the air in the wound by carbon dioxide (Myerly, Throckmorton, and Gustafson, 1957 ; Nichols, Morse, and Hirose, 1958 ; Ogawa, Kai, Seno, Taguchi, Kurihara, Fujimara, Kato, Hirano, and Adachi, 1962 ; Eguchi, Sakurai, and Yamaguchi, 1963 ; Effler, Groves, and Gulati, 1964; Burbank, Ferguson, and Burford, 1965). The solubility of carbon dioxide in blood is greater than that of air, in which nitrogen is the important relatively insoluble component (Table I). The

\section{T A B L E I}

OSTWALD BLOOD/GAS SOLUBILITY COEFFICIENTS AT $37 \cdot 38^{\circ} \mathrm{C}$.

\begin{tabular}{l|l}
\hline $\mathrm{N}_{3}$ & \\
$\mathrm{O}_{2}$ & 0.147 \\
$\mathrm{~N}_{2} \mathrm{O}$ & 0.027 (plasma/gas) \\
$\mathrm{CO}_{2}$ & 0.47 \\
& 4.0 \\
\hline
\end{tabular}

serious effects that follow air trapped in the arterial system should be diminished by replacing this air with an equal quantity of carbon dioxide. Animal studies support this argument. In dogs, five times the volume of carbon dioxide as compared with air injected into the left ventricle was necessary to produce the same mortality rate (Kunkler and King, 1959). Similarly in cats, Moore and Braselton (1940) found that the fatal dose of carbon dioxide injected into the pulmonary vein was 12 times that of air. Flooding the chest cavity with either carbon dioxide or air in dogs, with the left auricle wide open, gave an incidence of gross cardiovascular upset three times greater in those dogs that had air in the chest than in the carbon dioxide group. Furthermore, the injection of more than $0.5 \mathrm{ml} . / \mathrm{kg}$. of air into a common carotid artery in dogs always caused severe neurological damage (demonstrated at necropsy), $\vec{\phi}$ whereas 4 to $8 \mathrm{ml} . / \mathrm{kg}$. of carbon dioxide produced ${ }_{\infty}$ transient signs in only $33 \%$ of the dogs, all of which subsequently recovered completely (Eguchi et al., 1963).

Very little information is available as to the most effective means of maintaining a high carbon $ᄋ$

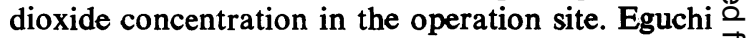
et al. (1963) studied this. They measured the levels $\overline{\bar{O}}$ of carbon dioxide in a model of the open chest at $\exists$ various flow rates. In their conclusions they stated that carbon dioxide at not less than $21 . / \mathrm{min}$. should be used. This is open to some doubt since, from their own experiments, this would provide a carbon dioxide concentration of only $x$ $55 \%$ at the surface of the incision. Moreover, the whole value of carbon dioxide flooding has been questioned by Effler et al. (1964), since they found that 'useful' although undefined levels of carbon dioxide were not present in the operating field. Unfortunately neither they nor Eguchi and his $>$ colleagues (1963) described the method by which the carbon dioxide was administered.

It seems that there would be a reasonable case ${ }^{\circ}$ for the use of carbon dioxide displacement during open-heart surgery if 'high' levels of carbon $\omega$ dioxide were reached in the operating field. The present study set out to determine the most effec-o tive means of doing this.

\section{METHODS}

Since the relative density of carbon dioxide compared with air is $1 \cdot 5: 1$ it tends to displace air by gravity. The factors which could affect the levels of carbon $\bar{\sigma}$ dioxide are: the volume of the cavity; the flow of 
carbon dioxide; the number of gas orifices opening into the cavity; the diameter of the orifices; the position of the orifices; the use of suction; and hand and other movements in the wound.

Model chest cavities were used; the dimensions were taken from measurements made on small and large patients (Fig. 1). Carbon dioxide from medical gas cylinders was allowed to flow into the model chest cavity through nozzles placed at the rim of the cavity.
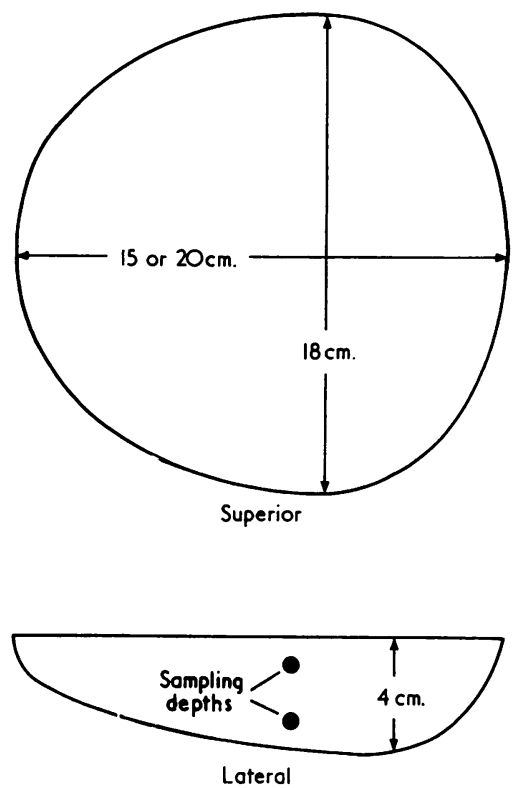

FIG. 1. Dimensions of model chest cavities.

The flow rates, the number of orifices, and the orifice sizes were varied. Air displacement was determined by measuring the oxygen concentration with a paramagnetic oxygen analyser (Beckman) which had been calibrated against gas samples of known oxygen concentration. The carbon dioxide concentrations determined indirectly by this method correlated well enough $( \pm 2 \%)$ with determinations with a $\mathrm{PCO}_{2}$ electrode. The results are shown in Table II.

\section{RESULTS AND DISCUSSION}

volume of CAVITY Since a thoracotomy cavity may vary in size we tested two cavities of 15 and $20 \mathrm{~cm}$. in length by $18 \mathrm{~cm}$. in width. A flow of $51 . / \mathrm{min}$. of carbon dioxide produced the highest carbon dioxide levels in both cavities, although it seems necessary to deliver the gas with two jets in the larger cavity.

\section{T A B L E I I}

EFFECT OF DIFFERENT FLOW RATES OF CARBON DIOXIDE, AND NUMBER AND SIZE OF DELIVERY NOZZLES, ON THE ELIMINATION OF AIR FROM MODEL CHEST CAVITIES

\begin{tabular}{|c|c|c|c|c|c|c|c|}
\hline \multirow{3}{*}{$\begin{array}{c}\text { Cavity Size } \\
\frac{\text { Large }}{20 \times 18 \times 4 \mathrm{~cm} .)}\end{array}$} & \multirow{3}{*}{\begin{tabular}{|c}
$\begin{array}{c}\text { Orifice } \\
\text { Dia- } \\
\text { meter } \\
(\mathrm{cm} .)\end{array}$ \\
0.05
\end{tabular}} & \multirow[b]{2}{*}{$\begin{array}{l}\text { No. of } \\
\text { Orifices }\end{array}$} & \multirow[b]{2}{*}{$\begin{array}{c}\mathrm{CO}_{2} \\
\text { Flow } \\
\text { Rate } \\
\text { (1./min.) }\end{array}$} & \multicolumn{4}{|c|}{$\%$ Elimination of Air } \\
\hline & & & & \multicolumn{2}{|c|}{$\begin{array}{c}\text { Central } \\
1 \mathrm{~cm} .3 \mathrm{~cm} \text {. } \\
\text { from } \\
\text { Surface }\end{array}$} & \multicolumn{2}{|c|}{$\begin{array}{l}\text { Peripheral } \\
1 \mathrm{~cm} .3 \mathrm{~cm} \\
\text { from } \\
\text { Surface }\end{array}$} \\
\hline & & 10 & \multirow{10}{*}{$\begin{array}{c}5 \\
10 \\
5 \\
10 \\
2 \cdot 5 \\
5 \\
7 \cdot 5 \\
2 \cdot 5 \\
5 \\
7 \cdot 5 \\
2 \cdot 5 \\
5 \\
7 \cdot 5 \\
5 \\
10 \\
5 \\
10\end{array}$} & \multirow{10}{*}{$\begin{array}{r}0 \\
4 \\
10 \\
12 \\
19 \\
48 \\
29 \\
38 \\
52 \\
48 \\
28 \\
48 \\
52 \\
52 \\
54 \\
48 \\
56\end{array}$} & \multirow{10}{*}{$\begin{array}{l}10 \\
14 \\
29 \\
24 \\
62 \\
71 \\
62 \\
57 \\
71 \\
67 \\
67 \\
80 \\
82 \\
82 \\
81 \\
84 \\
78\end{array}$} & \multirow{10}{*}{$\begin{array}{l}0 \\
2 \\
4 \\
4\end{array}$} & \multirow{10}{*}{$\begin{array}{l}10 \\
14 \\
29 \\
24 \\
45 \\
71 \\
55 \\
35 \\
50 \\
45 \\
60 \\
76 \\
76 \\
72 \\
72 \\
67 \\
72\end{array}$} \\
\hline & 0.2 & 10 & & & & & \\
\hline & 0.5 & 2 & & & & & \\
\hline & & & & & & & \\
\hline & 0.9 & 1 & & & & & \\
\hline & 0.9 & 2 & & & & & \\
\hline & & & & & & & \\
\hline & 0.9 & 3 & & & & & \\
\hline & & & & & & & \\
\hline & & & & & & & \\
\hline \multirow[t]{5}{*}{$\begin{array}{c}\text { Small } \\
(15 \times 18 \times 4 \mathrm{~cm} .)\end{array}$} & 0.9 & 1 & \multirow{5}{*}{$\begin{array}{l}2 \cdot 5 \\
5 \\
7 \cdot 5 \\
2 \cdot 5 \\
5 \\
7 \cdot 5 \\
5\end{array}$} & & \multirow{5}{*}{$\begin{array}{l}57 \\
81 \\
86 \\
52 \\
79 \\
86 \\
86\end{array}$} & \multirow{4}{*}{$\begin{array}{l}29 \\
57 \\
57 \\
33 \\
52 \\
67 \\
56\end{array}$} & $\begin{array}{l}48 \\
76\end{array}$ \\
\hline & 0.0 & $?$ & & & & & \\
\hline & 0.9 & 2 & & & & & \\
\hline & 0.9 & 4 & & & & & 81 \\
\hline & & & & & & & \\
\hline
\end{tabular}

FLOW RATE OF CARBON DIOXIDE We found, as did Eguchi et al. (1963), that a flow of about $51 . / \mathrm{min}$. of carbon dioxide provides a near maximum displacement of air; a greater flow did not give much improvement, and the displacement of air was adversely affected by a lesser flow.

NUMBER AND DIAMETER OF ORIFICES Jets of small diameter are unsatisfactory even if the gas flow is split up by flowing it through a number of jets ; this is probably because the gas velocity causes turbulence, entrainment of air, and dilution of carbon dioxide in the cavity. Jets of between 0.5 and $1 \mathrm{~cm}$. in diameter were found to give optimum carbon dioxide concentrations.

POSITION OF ORIFICES The jets were ineffective unless directed slightly downwards into the cavity. Their position at the periphery of the cavity in practice is governed by the available space. The most effective elimination of air in the central region of the cavity takes place when the jets are aimed at this region.

EFFECT OF SUCTION (Fig. 2) Continuous suction in the chest cavity rapidly reduces the carbon dioxide in the cavity which is aspirated into the pump oxygenator. This is a disadvantage, since some oxygenators may be incapable of removing 


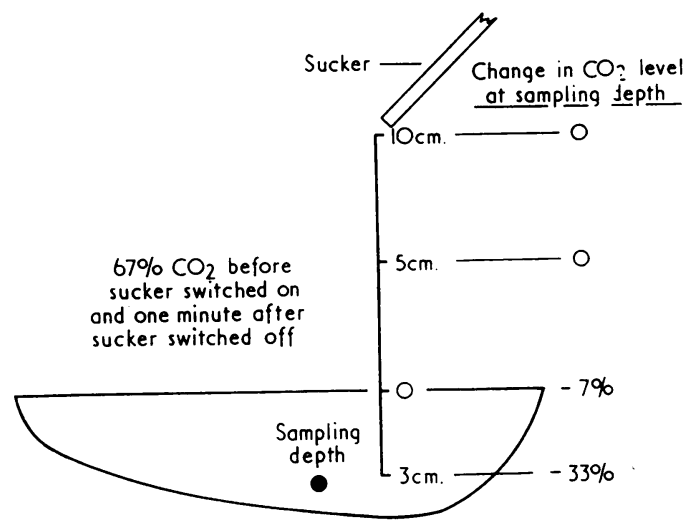

FIG. 2. Effect of position of a sucker at $20 \mathrm{l}$. per minute free flow on the carbon dioxide level in the model chest cavity.

all this extra carbon dioxide (Burbank et al., 1965). We found no alteration in carbon dioxide level in the cavity if a sucker, at $201 . / \mathrm{min}$. free air flow (which exceeds that used during open-heart surgery), was placed more than $3 \mathrm{~cm}$. above the cavity. After suction in the wound the original concentration of carbon dioxide returned within one minute.

Since the highest level of carbon dioxide in the cavity is reached quickly it seems unnecessary, and perhaps even undesirable, to use the carbon dioxide throughout the operation. Its use can probably be confined to the period just before closure of the heart or great vessel incision. This reduces the time during which the surgical team need be careful with suction as well as stress on the pump oxygenator.

HAND MOVEMENTS Hand movements in the cavity produced no measurable alteration in the level of carbon dioxide in the cavity.

OTHER ASPECTS Several other aspects were studied. Analysis of the air above the cavity showed that the concentration of carbon dioxide had fallen to less than $5 \%$ at $5 \mathrm{~cm}$. above the cavity surface, so that the surgical team should not be affected. Although carbon dioxide in medical gas cylinders is sterile (British Oxygen Company Ltd., 1966), nevertheless there is always some doubt about the connexions and tubing. Sterile tubing should be used and a bacterial filter placed in the line (Sussman, 1966).
The system is checked during the operation, to exclude such faults as leaks, by sampling the carbon dioxide levels in the wound.

The factors involved in substituting carbon $\frac{\text { के }}{\widetilde{\phi}}$ dioxide for air in the chest cavity during open- $\frac{1}{0}$ heart surgery have been investigated and thew precautions that should be taken are described. $\overrightarrow{0}$ Whether carbon dioxide substitution for air duringopen-heart surgery is useful should now be investi- $\vec{\omega}$ gated in a controlled trial.

\section{CONCLUSIONS}

Carbon dioxide at a flow rate of $51 . / \mathrm{min} . \vec{\oplus}$ delivered through two nozzles directed into theo chest cavity is optimum.

The nozzle should have a diameter of at leastz $0.5 \mathrm{~cm}$.

The carbon dioxide probably need flow only just before the risk of air embolization is present $\overrightarrow{x o}$ that is, at closure of the incision.

The sucker should be kept outside the incision except when a collection of blood requireso removal.

A bacterial filter is probably a safety measure.

The actual carbon dioxide level in the wound should be confirmed at operation.

We wish to thank Professor W. W. Mushin for his valuable advice, and Mr. E. K. Hillard, L.I.B.S.T. of the Department of Anaesthetics for the figures.

Part of this work was carried out by one of uso (W. S. N.) while holding the appointment of Research Fellow (supported by the United Cardiff Hospitals. Endowment Fund) in the Department of Anaesthetics. Royal Infirmary, Cardiff.

\section{REFERENCES}

Burbank, A., Ferguson. T. B., and Burford, T. H. (1965). Carbon dioxide flooding of the chest in open-heart surgery. $J$. thorac cardiovasc. Surg., 50, 691 .

British Oxygen Company Ltd. (1966). Personal communication.

Effler, D. B., Groves, L. K., and Gulati, K. (1964). Open surgervo upon the mitral valve: prevention of air embolus. Clevelanit clin. Quart., 31, 107.

Eguchi, S., Sakurai, Y., and Yamaguchi, A. (1963). The use of CO N gas to prevent air embolism during open heart surgery. Acta ned. biol. (Niigata), 11, 1 .

Kunkler, A., and King, H. (1959). Comparison of air, oxygen and carbon dioxide embolization. Ann. Surg., 149, 95.

Moore, R. M., and Braselton, C. W. (1940). Injections of air and otD carbon dioxide into a pulmonary vein. Ibid., 112, 212.

Myerly, W. H., Throckmorton, T. D., and Gustafson, J. E. (1957) The closure of cardiac septal defects. Arch. Surg., 74, 918.

Nichols, H. T., Morse, D. P., and Hirose, T. (1958). Coronary an $\overline{0}$ other air embolization occurring during open heart surgery prevention by the use of gaseous carbon dioxide. Surgery, 43,236

Ogawa, S., Kai, T., Seno, Y., Taguchi, K., Kurihara, Y., Fujimara $\overparen{D}$ K., Kato, K., Hirano, K., and Adachi, I. (1962). Study on controlled hypothermic selective cardiac cooling. J. Jap. surg. Soc., 63, 873 .

Sussman, M. (1966). Personal communication. 